\title{
FEITIÇARIAS, TERRITÓRIOS E RESISTÊNCIAS MARGINAIS
}

Patricia Birman

\section{Introdução}

O que está acontecendo com o emprego da feitiçaria nestes tempos pentecostais? A palavra pentecostal na enunciação de atos de feitiçaria aparentemente tem falado mais alto e com mais vigor do que quaisquer outras nos tempos atuais. Tudo indica, ao menos no Rio de Janeiro, que acusações de feitiçaria têm circulado principalmente, e com especial intensidade, nos lugares onde se mostra acentuado o combate pentecostal ao mal diabólico: favelas e outras periferias, em geral designadas como comunidades. Os evangélicos, no cotidiano, através de menções à feitiçaria, cuja origem estaria nos cultos afro-brasileiros, denunciam crimes nefandos e atos de barbárie, provocando horror e estarrecimento nos seus ouvintes em igrejas, rádios e televisão. Vou descrever aqui dois casos de acusação de feitiçaria que articulam marginalidade, crime e presença do mal diabólico em duas comunidades. Para melhor entender as acusações de feitiçaria, é preciso considerar que tanto a comunidade de crentes quanto a favela onde realizei trabalho de campo ${ }^{1}$ apresentam para seus moradores dificuldades que resultam da sua administração como territórios submetidos a formas específicas de identificação promovidas pelo Estado. Este identifica seus habitantes através de categorias que produzem efeitos de exclusão e de inclusão que dialogam com os valores sociais e políticos associados às religiões e à feitiçaria. Embora a feitiçaria não seja "um produto do Estado e um modo de apropriação deste", ${ }^{2}$ ela se encontra intimamente vinculada aos procedimentos por meio dos quais o Estado define e se relaciona com populações situadas às suas margens. ${ }^{3}$

De início, quero assinalar o paulatino desenvolvimento de uma afinidade na mídia e no espaço público entre o discurso evangélico e os discursos laicos na elaboração da temática do mal e da violência. Os evangélicos, ao relacionarem as acusações de feitiçaria às práticas criminosas e ao banditismo, estão, com efeito, enfatizando o que a mídia laica não se cansa de destacar: a presença de um potente inimigo interno, o "bandido", ou o "traficante", que 
vive nas "comunidades", potencializando assim a imagem negativa destas como totalidades culturais que são estigmatizadas como fontes de perigo e de violência para a sociedade. ${ }^{4}$ Levando em conta a importância dessas percepções das margens para o que têm sido as políticas implementadas nesses espaços assim configurados, vemos que os discursos de diabolização de tais territórios constituem uma forma de ação político-religiosa que, simultaneamente, reage às acusações do Estado e se apropria de suas categorias, conjugando-as com suas concepções religiosas.

Uma distância de mais de dez anos separa as situações em que vou me deter, ambas frutos de experiências de pesquisa com grupos evangélicos em comunidades. A primeira se passou em uma favela, situada na zona sul do Rio de Janeiro, e a segunda, em um território designado como uma comunidade de crentes, a quatro horas de distância da cidade do Rio de Janeiro. As duas experiências de pesquisa, postas aqui em relação, permitiram-me iluminar em um e em outro contexto os sentidos que, em circunstâncias precisas, adquiriram as acusações de feitiçaria, sempre associadas aos diabos afro-brasileiros e aos espaços sociais concebidos, de modo dominante, como territórios que abrigariam comunidades homogêneas, como se estas fossem totalidades culturais.

Viso destacar, por meio desta comparação, como o projeto evangélico nos territórios de favela tem como horizonte aquilo que, na comunidade de crentes, supostamente já se encontraria em vigor, a saber, uma vila onde a lei de Deus configura o seu espaço público com a caução do Estado. A comunidade de crentes realizaria ali, ao menos idealmente, o imaginário de ordem que o pentecostalismo gostaria de conquistar em todos os espaços sociais nos quais ele atua.

Como os anos que separam as duas experiências de pesquisa foram de consolidação do evangelismo no país, as situações que relato, nas suas especificidades de todos os pontos de vista, também dizem respeito à passagem do tempo, relativa à crescente acumulação de poder e de influência por parte dos grupos evangélicos, principalmente no Rio de Janeiro. O tempo, com efeito, não é algo negligenciável em relação à presença evangélica e menos ainda no que diz respeito aos problemas que os grupos sociais aos quais estes religiosos pertencem vêm enfrentando na sociedade brasileira. A conversão a essas igrejas, como sabemos, tem se dado principalmente entre os grupos sociais subalternos. São os indivíduos provenientes destes grupos que têm sido, ao mesmo tempo, testemunhas, vítimas e atores das reconfigurações das margens constantemente referidas à violência e à criminalidade e ao seu par religioso, a magia e a feitiçaria. Estas reconfigurações participam da elaboração das periferias como espaços sociais de exceção, que aqui se revelam como espelhos invertidos: na favela imperaria o crime e a desordem, 
e os evangélicos almejam ser os atores sociais política e religiosamente responsáveis pela expulsão do mal desta e de outras comunidades. Na comunidade de crentes, este horizonte já teria sido parcialmente alcançado pelo poder que desfruta a igreja pentecostal do lugar. Esta conduz e alimenta a luta dos seus fiéis para conservar o mal externo às suas fronteiras, através de um controle efetivo do seu espaço público.

$\mathrm{Na}$ sociedade brasileira, em que as figuras da desordem constituem uma referência constantemente relacionada às suas periferias, temos acompanhado nos últimos 15 anos, talvez mais, um processo que incide na definição de seus espaços e de suas fronteiras. Refiro-me à emergência da "violência" como uma questão social na cidade do Rio de Janeiro, que se apresenta como um produto "evidente" dessas periferias, como a favela. A designação de alguns espaços sociais de moradia como favela tem uma longa história, associada a modalidades variadas de construção de alteridades, como aquelas ligadas à marginalidade, à falta de civilização, à pobreza. A esta última categoria, a pobreza, adicionou-se a criminalidade, através da identificação de seus moradores com o tráfico de drogas e com a violência. Ao longo dos anos esta identificação foi progressivamente naturalizada, o que contribuiu para aumentar a insegurança dos moradores, cada vez mais ameaçados de morte violenta nos seus territórios de moradia (Machado da Silva e Leite 2007; Machado da Silva 2007; Farias 2008). ${ }^{5}$

Busco assim explorar, em primeiro lugar, como moradores de favela estão expostos a identificações do Estado como indivíduos associados ao crime e à violência, por um lado, e a interpelações dos traficantes que controlam este mesmo território pela força das armas, por outro. Vou me deter em um evento em que estas modalidades de relação se articulam com a mudança da economia de trocas religiosas neste espaço através da presença evangélica. Para isto, valorizarei os argumentos do relato de uma antiga religiosa do candomblé que viveu situações extremamente ameaçadoras, nas quais o perigo de perder sua vida apresentou-se associado a uma causalidade mágica.

Após este relato, eu me voltarei para as práticas pentecostais em uma comunidade de crentes, onde o modo de intervenção da Assembleia de Deus não teve até agora rivais à sua altura. ${ }^{6}$ Habitada majoritariamente por famílias pertencentes à única igreja local, ${ }^{7}$ o seu território é percebido como detentor de qualidades religiosas diferenciais. Este seria, de fato, um lugar santificado. Pretendo explorar aqui o sentido de uma acusação de feitiçaria praticada nesta comunidade, na qual as interpelações do Estado reconhecem a diferença moralmente positiva que ela apresenta para a sociedade.

É dessa vila abençoada que os seus moradores assistem na televisão ao espetáculo incessante do mal no mundo, reassegurando-os sobre a natureza 
especial do lugar onde vivem. ${ }^{8} \mathrm{O}$ mal diabólico nesta comunidade de crentes, embora onipresente e ameaçador, estaria situado em suas margens, já que o território da comunidade possui uma sacralidade que o distingue de outras, como a da citada comunidade de favela, cuja imagem predominante vincula-a ao crime e à violência. As relações dos evangélicos estabelecidas com e através destes territórios se dão tendo como pano de fundo uma percepção da dinâmica do mundo estruturada através das forças do mal. Estas, no entanto, participam de embates específicos e agem diferencialmente nos seus espaços devido à interferência dos homens de Deus e daqueles outros sob o domínio dos diabos. A Batalha Espiritual explica os acontecimentos na esfera pública e revela a presença diabólica aos olhos de diferentes religiosos, como veremos a seguir. ${ }^{9}$

\section{Territórios, Pessoas e Relações}

Assinalemos que o contraste entre estas duas comunidades não seria tão marcante se não fizesse parte de suas histórias a elaboração progressiva, no espaço público, de um novo valor atribuído à identidade evangélica. Personagens recentes na economia religiosa da cidade, os chamados "crentes" ou "evangélicos" ${ }_{1}^{10}$ ganharam reconhecimento público no mesmo momento em que se construiu a "violência" como um "problema social" (Birman e Leite 2000). Com efeito, nos anos 90, na grande imprensa e na mídia televisiva, novas temáticas emergiram: de um lado, escândalos provocados pelo surgimento da IURD, acompanhamentos sucessivos desses novos protagonistas religiosos no espaço público (cf. Soares 1993; Giumbelli 2002; Mariano 1996)e, de outro, referências cotidianas a uma criminalidade organizada que controlaria segmentos progressivamente mais amplos da população pobre das grandes cidades. Uma face perturbadora da vida social, crescentemente espetacularizada pela mídia, apelaria constantemente para um combate a ser realizado pelas forças da ordem contra o mal da violência e seus responsáveis. Mas a esta violência, embora genérica, foi atribuída uma residência preferencial. Foi em certos territórios que o Estado passou a buscar (e também a provocar) suas ocorrências mais importantes.

Se não é de hoje que se afirma uma relação entre territórios periféricos e qualidades morais negativas, associadas à pobreza e à criminalidade, é relativamente recente a associação entre o conjunto assim constituído e certas práticas religiosas, como o exorcismo e o chamado constante por intervenções evangélicas. A leitura demonizadora da mídia religiosa - cujo poder se afirmou a partir dos anos 90 - dialoga e complementa a temática que, ao longo 
dos últimos 15 anos ou mais, predomina amplamente na mídia laica carioca. Cada qual ao seu modo intensificou uma percepção negativa dos que vivem nos espaços periféricos da cidade (Cf. Machado da Silva e Leite 2007).

Martijn Oosterbaan (2006) argumentou de modo particularmente feliz sobre a presença de uma intertextualidade dos discursos sobre o Mal pentecostal e a descrição midiática da violência associada ao tráfico de drogas nas favelas do Rio. Assim, o mesmo espetáculo do mal, cujo absurdo desafia a consciência moral de leitores e telespectadores, reafirma a periculosidade das camadas populares, e também o universo destas como aquele que seria mais permeável a atos imorais e também à feitiçaria. ${ }^{11}$

No entanto, a continuidade entre os discursos laicos e religiosos é também relativa. Com efeito, a possibilidade de conversão transforma a relação que estes supostos criminosos teriam com o mal e com a morte, que é o destino que a sociedade lhes reserva majoritariamente. Os evangélicos trabalham sem cessar para que o vínculo com o mal diabólico se transforme, de fato, em algo provisório e superável. O destino dos criminosos e dos traficantes pode ser aquele que os espera como convertidos, cuja condição lhes asseguraria um novo "direito" à vida. Assim, o trabalho incessante de orações e de exorcismo visaria também evitar a abolição do futuro dos que participam dessa lógica de guerra. As igrejas pentecostais contribuem, pois, de certa forma para a diabolização de jovens traficantes e dos moradores desses espaços periféricos, buscando, no entanto, por intermédio das atividades religiosas, assegurar-lhes a vida, afastando-os do mundo terreno que a condição de favelado coloca permanentemente em perigo. A figura do inimigo irreconciliável é, para os evangélicos, o diabo, e não as pessoas que vivem ou viveram submetidas às forças do mal. Neste aspecto, distanciam-se da percepção do Estado para quem bandidos são configurados como outros absolutos a serem até mesmo exterminados em defesa da sociedade.

Inúmeros testemunhos nas igrejas evangélicas conclamam repetidamente que a intenção do diabo é sempre roubar, matar e destruir. E do púlpito relatam os males que fizeram antes de aceitar Jesus. É, no entanto, desta condição degradada, de pessoa submetida às forças do mal, que emerge uma nova, salva pelo Evangelho. Daí decorre, como parte deste jogo especular, que nada mais próximo de um bandido do que um crente. ${ }^{12}$ Isto porque, segundo os testemunhos ritualizados nos cultos, os evangélicos (principalmente os homens) teriam sido, no seu passado, como pecadores que foram um pouco "bandidos". Um tempo liminar participa assim do processo de formação dos homens, que podem, entretanto, encontrar nas igrejas evangélicas a libertação. O caminho de bandidos a evangélicos seria não somente desejável, como também se constituiria hoje no horizonte mais evidente para 
os que, nas periferias, se encontram em uma interlocução constante com a criminalidade e com o seu combate promovido pelo Estado.

Assim, as duas comunidades que abordo aqui volta e meia são objeto de definições por meio destes antagonismos. Ambas revelam a importância desse eixo religioso que ressalta a incompatibilidade absoluta entre o Bem e o Mal. Os dois casos de feitiçaria que analisarei a seguir, com efeito, fazem sentido para seus protagonistas enquanto pessoas que participam das dinâmicas de seus locais de moradia. São informadas também pelos discursos que buscam defini-las e circunscrever seus comportamentos e conflitos relacionando-os a este esquema dualista, particularmente desenvolvido pelo pentecostalismo e também pelos discursos laicos que estigmatizam os territórios periféricos onde habitam os pobres.

Apresentemos nossos personagens. Alice provém do candomblé e se relaciona com as suas entidades afro-brasileiras no quadro de uma "guerra" do tráfico numa favela carioca, lugar frequentemente identificado pela relação com o Mal e com a feitiçaria. Bruno e Carlos se relacionam com o diabo e suas entidades da macumba nas margens de um espaço público que tem uma igreja evangélica no seu centro. ${ }^{13} \mathrm{Na}$ favela, todos os gatos ao menos parecem pardos quando a polícia busca, no meio de uma área densamente ocupada, atirar nos supostos bandidos. A dificuldade das forças policiais de definirem e acertarem os alvos de seus tiros - e somente eles, assinalemos - quintuplica-se como problema para os seus habitantes. Em outras palavras, demanda-se dos moradores um esforço contínuo para se apresentarem como exceções morais no interior de uma comunidade cujo caráter cultural abrangente é dado a priori. E lá os evangélicos exibem as marcas da santidade, as quais os excluem do princípio de identificação que legitima o comportamento violento da polícia no interior desta unidade territorial considerada socialmente nefasta.

Na comunidade evangélica, o pastor chama para si essa função identificatória, definindo as modalidades de observação e suas consequências para os indivíduos. Como guardião único da comunidade, garante para os representantes do Estado a fidelidade dos seus moradores à doutrina da igreja, o que contrasta com a favela, onde o Estado e a sociedade abrangente, a princípio, seriam convidados, em função da falta desta unidade políticoreligiosa para separar o joio do trigo em um celeiro de qualidade moral duvidosa. Na comunidade de crentes, o projeto de ordem da Assembleia de Deus local não prevê espaço para o anonimato, e as categorias de pertencimento devem se encaixar com precisão nas formas de ocupação pela igreja do seu território e na relação que esta busca cultivar com os representantes dos governos estadual e municipal. 


\section{Alice e a piscadela de Exu}

Faz parte da experiência dos moradores desta favela, como Alice, conviver com os discursos pentecostais que se oferecem como uma alternativa ao poder que se exerce em nome do Estado e da facção do tráfico local. Nas dinâmicas sociais e políticas encontradas nesta favela, Alice precisa se mover reconhecendo as armas dos traficantes, bem como o fato de estes também terem dado provas da própria importância política ao controlarem o território como detentores de um poder soberano. ${ }^{14}$ Viu crescer entre suas vizinhas estratégias de vida diferentes das suas, a partir da conversão que as encaminhou principalmente à IURD e também à Igreja Batista e à Assembleia de Deus do lugar.

Suas vizinhas, mulheres de cerca de 40 e 50 anos, antigas frequentadoras de casas de culto afro-brasileiras, pareciam ter reconhecido a emergência de um novo poder de mediação no local, acompanhado pela decadência que se abateu sobre o pai-de-santo de umbanda. Contrastando com Alice, ainda vinculada ao candomblé, uma moradora, dona de uma pequena birosca, era o testemunho vivo do que as igrejas pentecostais podiam oferecer: ela exalava satisfação e não escondia o quanto se orgulhava do seu filho, que tinha se transformado em pastor da Igreja Universal. Inegavelmente, o novo cargo de seu filho representava um passo importante em termos de ascensão social, acompanhado por certa notoriedade e prestígio na comunidade. E a filha de Alice, longe de obreiros e pastores, namorava neste momento um filho biológico desse desprestigiado pai-de-santo. Para desgosto de Alice, que desaprovava o namoro de sua filha, o jovem, além do mais, estava ligado ao tráfico, e o irmão dele, inclusive, tinha sido assassinado no ano anterior. A situação de Alice configurava-se como particularmente negativa: do ponto de vista religioso, não tinha se integrado ao grupo que então apresentava uma mobilidade social ascendente e, para completar, sua filha estava visivelmente identificada com o mal diabólico, por seu pertencimento à macumba e por sua ligação indireta com o tráfico.

No final dos anos 90, no auge dos ataques que a Igreja Universal do Reino de Deus fazia aos cultos afro-brasileiros, Alice contou-me o porquê do seu abandono do candomblé, após 30 anos de dedicação aos seus orixás. Naquela época, eu estudava a conversão dos afro-brasileiros ao pentecostalismo e afirmei como hipótese de trabalho uma continuidade importante entre as antigas práticas dos cultos afro-brasileiros e as pentecostais. Hoje, considero que, ao enfatizar as relações de continuidade entre os dois cultos, não valorizei o projeto de ruptura que informava o desejo de mudança dos seus praticantes e que respondia também a um modo de elaborar as 
transformações de suas condições de vida (Birman 1996). ${ }^{15} \mathrm{E}$ assim retomo o relato de Alice com esta nova preocupação. Quando desta conversa, ela deveria estar na faixa dos 40 anos e trabalhava como faxineira em casas de classe média alta no Rio.

A sua maior fonte de preocupação eram, então, os riscos pelos quais sua filha passava. Entre as pessoas que eu conheci ali, nesta pequena favela, as duas se configuravam como exceção: estavam entre as poucas pessoas que não escondiam o elo cultivado com o candomblé e faziam deste pertencimento religioso um eterno motivo de conversas: eram capazes de falar horas a fio da beleza das "festas de santo" e do prazer que tinham com isto. ${ }^{16}$

Voltemos às circunstâncias do seu abandono do candomblé. Trata-se de uma história que Alice relacionou a um conflito entre dois grupos do tráfico que disputavam a ocupação de pontos de venda de drogas na favela. Alice fez um relato emocionado em termos religiosos da luta entre os grupos de tráfico e dos efeitos que esta gerou na sua vida. Contra a sua vontade, viu-se em parte responsável pelas mortes que ocorreram na guerra entre traficantes e destes últimos com a polícia que quase matou a sua filha.

Um dia, conta ela, voltando do trabalho, encontra a sua casa transformada em esconderijo das armas do namorado da filha. Ficou indignada, exaltou-se e dirigiu-se aos gritos ao jovem, expulsando-o dali e obrigandoo a levar todo o seu arsenal com ele. Mas a filha continuava o namoro e a situação só se agravava, aumentando os seus receios. No auge da raiva e da indignação com o risco que o jovem estava provocando na sua vida, Alice proferiu um dia em voz alta, na rua, sob a escuta curiosa dos vizinhos, um pedido de vingança que se realizaria através da interferência do seu Exu. Seu pedido a Exu era nada menos que ele providenciasse o desaparecimento do jovem da vida da sua filha.

Infelizmente, pouco tempo depois, a favela é invadida pela facção rival do tráfico e o jovem morre no tiroteio, nos braços de sua filha que, por pouco, não é atingida. Alice escuta os tiros, sai para a rua e cruza com o assassino com a arma na mão, que desce a ladeira onde mora, deixando atrás de si o corpo do seu inimigo no chão. O assassino, destaca, que não era dali, ao passar por ela faz um gesto de cumplicidade, pisca os olhos e se deixa identificar por Alice como o "seu" Exu, aquele mesmo a quem ela pedira vingança e com quem tinha uma relação privilegiada no candomblé. Não bastasse isto, este jovem vira o novo "dono do morro" e passa a namorar a sua filha, oferecendo-lhe todas as riquezas que o tráfico pode comprar. Ela, sabendo que o novo dono do morro é o "seu" Exu "incorporado" em um jovem traficante, não pode sequer protestar. Finalmente, é a vez de a polícia invadir o morro. O jovem tenta fugir, mas é crivado de balas e cai. O seu 
corpo tomba num despenhadeiro, chocando-se com uma grade de ferro que o perfura e o mata. Ela o viu morrer. Nesta hora, ele ainda teve fôlego de se apresentar por um segundo, sob a imagem tradicional do Exu, vestido de Zé Pilintra, ${ }^{17}$ tal como ela o reconhecia nas festas do candomblé.

A dramaticidade contida nesta narrativa faz do abandono do candomblé uma decorrência moral e social quase obrigatória: seria impossível continuar em uma religião que, além de nunca ter lhe dado prosperidade, frisa — nunca foi rica e tampouco conhece uma mãe-de-santo que tenha ficado - coloca-a no meio de guerras faccionárias violentas que transformaram um gesto impensado seu numa tragédia sangrenta que jamais desejou. Mas não somente isto. O apelo que Alice fez à entidade é percebido como a causa das mortes dos jovens. Passou então a se ver, ao menos parcialmente, como responsável ou, talvez, o mais importante, como uma fonte de incriminação por parte de um dos grupos que participam desta "guerra". Através dos comentários de vizinhos, por exemplo, esta relação poderia ganhar outro contorno e assim dar um tom ainda mais realista à imagem negativa que já seria a sua como candomblecista.

O Exu de Alice, como vemos, adquiriu um perfil que se assemelha àquele atribuído pelos pentecostais às entidades afro-brasileiras: mostrou-se sob uma face demoníaca, comprometida com o Mal e responsável por crimes executados por traficantes e polícia, disseminando o terror e a morte. Este Exu quis servi-la de um modo que, após este evento, ficou claro para ela que seria inaceitável. A morte violenta, ao ter sido relacionada por Alice ao seu Exu, transformou-a, ao menos em sua imaginação, num novo sujeito no interior do espaço onde mora: alguém cuja agência seria maléfica por englobar a ação das entidades afro-brasileiras. Ganhar autonomia em relação a estas entidades, libertar-se delas, como dizem os membros da Igreja Universal do Reino de Deus, passou a ser necessário não somente para defender a sua imagem mas, sobretudo, por discordar do comportamento do Exu.

Agora Alice se diz "sem religião". Apesar de estar rejeitando as suas antigas relações com os santos do candomblé, não passou a ver na entrada para uma igreja pentecostal uma exigência a cumprir. No entanto, Alice achava bom ir às igrejas evangélicas. Foi junto com sua filha a cultos na Igreja Batista Renovada, na Assembleia de Deus, na Igreja Universal, mas não teve vontade de largar nem o cigarro nem a cerveja, nem tampouco de abandonar os seus casos amorosos. Não se converteu. Mas, de alguma maneira, ela foi confrontada com uma exigência de transformação própria que dificilmente poderíamos compreender sem levar em conta todos os elementos que participaram da situação tal como ela nos descreveu.

Outra percepção sobre as suas entidades religiosas passou a se impor: verificou que estas são capazes de responder com violência no interior de 
um mundo que se apresenta marcado por antagonismos irreparáveis, solucionados principalmente por intermédio da força física. Entes que sempre foram sujeitos, como ela própria, a cultivar cumplicidades, a tomar partido e a se envolver com as causas daqueles que os protegem agora seriam agentes de um mal absoluto. A acusação de uma possível cumplicidade torna-se mais complexa na medida em que envolve as concepções de troca nos cultos afro-brasileiros e seu combate pelos pentecostais num quadro de permanente interpelação por parte do Estado, que afirma a natureza maléfica da comunidade.

Com efeito, são vários os argumentos do Estado e da mídia a favor do colaboracionismo dos habitantes de favelas com o tráfico de drogas. Já se destacou, por exemplo, que devido ao fato de esses moradores terem laços de parentesco e de afinidade com os bandidos, isto os levaria a protegê-los contra as tentativas do Estado de identificá-los, discriminando-os de suas redes de relações. $\mathrm{O}$ fato de traficantes e moradores pertencerem a uma teia de relações é interpretado, pois, como uma adesão moral ao poder despótico exercido pelo tráfico. A delação para o Estado seria a forma correta de manifestar uma ausência de cumplicidade, segundo disseram o prefeito da cidade do Rio e o secretário de Segurança Pública por várias vezes em anos recentes. O silêncio, por sua vez, é imposto aos moradores pelos traficantes como meio de se garantir uma não-cumplicidade destes com a polícia. As fofocas que circulam entre vizinhos são fontes importantes para o tráfico identificar e punir, eventualmente com a morte ou mutilações, possíveis delatores (Cf. Machado da Silva \& Leite 2007; Vital da Cunha 2009).

Em outros termos, uma intervenção religiosa no interior de relações de família ganhou uma dimensão pública e política relacionada à guerra do tráfico e da polícia: a violência entrou por meio desta na casa e passou a ser também um assunto de responsabilidade de Alice. Contudo, este encadeamento que aponta para relações de causalidade entre os homicídios e as entidades afro-brasileiras não teria se estabelecido se algo não tivesse alterado a própria percepção de Alice a respeito de suas entidades de candomblé.

Alice não contou a sua história como uma mudança que tenha ocorrido na sua forma de perceber as coisas, mas como uma mudança na sua relação real com a sua entidade, que se transformou no interior das relações violentas existentes na favela. A entidade agiu como um ser autônomo e, ao fazê-lo, comportou-se como um diabo pentecostal, provocando destruições em todas as relações que antes cultivara. O personagem familiar, como o namorado da filha, foi vítima de uma ação mágica que o visava não mais como membro de um circuito de trocas que teria Alice como mediadora, 
mas como uma das faces de um mal universal: o diabo que age no interior da favela onde mora. ${ }^{18}$ Perder o seu papel de mediação significou neste caso não poder controlar os ataques e os contra-ataques mágicos que participavam do seu cotidiano religioso.

O seu Exu, agora diabo, agiu portanto como veículo de um mal absoluto que a teria tido como seu cúmplice. Ao ganhar autonomia em relação à Alice, ele revelou uma natureza transcendente, isto é, a submissão a um princípio que ultrapassa e determina os locais onde age. O diabo, em qualquer circunstância, é um diabo: tem o seu comportamento definido pelo seu estatuto de inimigo de Deus. E é através do combate cósmico aos princípios divinos do Bem, desde a origem do mundo, que se pode apreender o sentido maléfico de sua ação. Se tivesse privilegiado, para orientar o seu comportamento, os vínculos com Alice, dificilmente teria provocado a morte de duas pessoas próximas a ela. Longe de beneficiá-la como um ente que participa da sua vida e se encontra ao alcance (ainda que relativo) do seu poder, causou um mal que só se compreende pelo seu caráter absoluto e universal, quer dizer, reconhecível como o mesmo em qualquer lugar e em qualquer circunstância. O Exu/diabo destruiu, ao menos ali, o circuito de trocas de Alice, no qual ela exercia o seu poder de mediação através das suas entidades para responder às demandas de seus parentes e amigos. ${ }^{19}$ Em consequência, indiretamente ele encaminha os que querem se proteger de suas ações a se desconectarem de suas raízes religiosas locais e redefinirem a si mesmos por vínculos que transcendem o mundo terreno e particularmente aqueles do lugar onde moram.

A relatividade do mal, dominante na magia do candomblé e tão destacada nos trabalhos acadêmicos sobre ele, foi assim desmascarada pelo olhar severo dos pentecostais, e também pela identificação estigmatizante da favela promovida pelo Estado. Ao invés de conseguir um favor do seu Exu, no caso, o afastamento do namorado de sua filha, obteve deste um desmentido a respeito da natureza benéfica (ou ao menos ambivalente) das intervenções mágicas do candomblé a seu favor. A própria entidade confirmou inesperadamente o quanto a sua ação no presente ultrapassava largamente o controle de Alice sobre ela. Podemos concluir o caso de Alice dizendo que ela viveu uma experiência cujo significado maior foi o de ter perdido algumas de suas possibilidades de intervenção no mundo em que vive. Esta experiência parece ser traduzida com facilidade em termos religiosos pentecostais: afinal, quem, senão Deus, para se opor à violência dos incontáveis demônios que controlam a vida neste mundo? E, no caso da comunidade onde vive, talvez seja melhor considerar, como muitos outros, a intervenção divina como a única capaz de garantir aos seus moradores a possibilidade de transcender o mal que percorre e define incansavelmente o seu território. 


\section{As risadas da Pomba-Gira}

No território onde moram Carlos e Bruno, como já mencionamos, o pastor tem a caução do Estado para gerir os serviços públicos da comunidade, bem como para garantir a sua ordem social e moral. Mas não estaríamos fazendo justiça à importância da sua igreja se indicássemos este domínio simplesmente como de natureza política, desconsiderando a elaboração religiosa do seu território. As formas de controle do seu território e os exercícios de autoridade da igreja submetem as concepções seculares - que teoricamente, ao menos, embasariam as ações do Estado - aos princípios que fariam dessa comunidade um coletivo peculiarmente abençoado por Deus. A identificação evangélica da comunidade, até agora, tem se apresentado como a única fonte de legitimidade reconhecida para o exercício do poder diante do Estado.

Para melhor compreender os procedimentos da igreja é preciso, no entanto, nos voltarmos para a forma como esta concebe a intervenção divina junto a seus membros e sobre o território onde estes vivem. Com efeito, desde as primeiras viagens que fizemos à vila, tomamos conhecimento do seu mito de fundação. Ouvimos, pois, a história de um indivíduo evangélico que, ao retornar ao lugar onde teria nascido, um pequeno vilarejo de pescadores, começa a pregar o Evangelho e a converter progressivamente os seus habitantes. Ao se converterem, os seus moradores viraram testemunhas de um milagre que os atingiu pessoalmente e também redefiniu a totalidade do território em que habitavam. Deus interveio modificando as condições naturais do lugar e a ordem social, política e moral imperante no que então veio a ser Seu território. As três gerações que sucederam a esta primeira, alvo imediato da conversão e testemunha ocular de seus efeitos miraculosos, são apontadas como as beneficiárias das transformações que Deus efetivou naquele momento fundador.

Permito-me aqui retomar a narrativa desta reconversão do território (Birman 2006a). Alguns acidentes geográficos são assim reconhecidos como signos desta eleição. Próximo à entrada da baía, do barco de pesca que nos transporta, é possível ver na costa uma enorme pedra equilibrada sobre outra. Esta estranha escultura em rocha é frequentemente mencionada como uma comprovação da escolha divina. Numa apropriação pouco ortodoxa do reconhecimento que os índios, primeiros habitantes do país, fizeram da catolicidade da Terra de Santa Cruz, vemos estes testemunhos que, em outros tempos, asseguraram o ato inaugural de fundação do Brasil, fornecerem para os moradores a prova bíblica da ação divina. As lideranças da igreja percebem, em consequência, a vila como uma "comunidade" ter- 
ritorial e moral, cujos habitantes são os herdeiros naturais da graça divina, obtida ou talvez revelada pelo esforço missionário da igreja e pelos milagres do Espírito Santo. "Aqui foi um lugar que Deus escolheu para ele", formulou para nós um membro da igreja, que assim nos explicou porque os "de fora" precisam respeitar "a nossa cultura".

Em suma, a comunidade se realiza idealmente na imagem de um território cujas fronteiras foram estabelecidas por meio desta ruptura primordial, a partir da qual ela começou verdadeiramente a existir. A ruptura com o passado, diferente da maioria das histórias de fundação das igrejas pentecostais que conhecemos, se fez através de um princípio territorial englobador, o que deu origem a um aparente "isolado" religioso, a comunidade de crentes, cuja fundação parece lhe garantir um estatuto político específico: neste "lugar" a lei dos homens se dobrou à lei de Deus, o que é reconhecido por todos, de "dentro" e "de fora". No cotidiano, o pastor reafirma e busca exercer a sua autoridade sobre o conjunto da vila.

Cabe ressaltar, contudo, a tensão que acompanha a presença entre os religiosos das duas premissas doutrinárias parcialmente contraditórias que informam a sua ação: a primeira assegura o caráter individual da fé e do vínculo a ser cultivado com o Espírito Santo, e a segunda elabora este vínculo como prévio à existência dos indivíduos - atribuído a eles pelo fato de serem descendentes do ancestral fundador do território. A formação religiosa de cada um não deixa dúvidas quanto à importância atribuída por eles próprios à sua "estruturação pela Palavra" como indivíduos. No entanto, a incorporação do ethos pentecostal é vista como o destino daqueles que são os herdeiros naturais do Evangelho no lugar. A noção de "cultura evangélica", ao ser utilizada, ressalta além da dimensão patrimonial e totalizante que possui esta herança divina, a presença de um espaço de negociação com os "não-crentes" e os "de fora" da comunidade. Constituiu-se, pois, na comunidade uma ideologia de pertencimento e de adequação a um modo de vida particularmente uniforme que igualmente provoca inúmeras tensões entre certas categorias de moradores e a igreja.

Mas a gestão do pastor sobre o conjunto do território provoca também certo desconforto num outro grupo - aquele dos desviados da igreja, que se vê às vezes tratado com excessivo rigor. A categoria desviado, habitualmente utilizada pelas igrejas pentecostais, indica uma posição de afastamento de membros em situação de pecado. Esta categoria designa aqui um grupo de idade, os jovens, filhos homens das famílias pentecostais. Os desviados comportam-se como se estivessem "no mundo", desfrutando de seus prazeres e pecados, até se casarem e se tornarem adultos, pais de família (Cf. Birman 2008; Bakker 2008; Cretton 2007). 
Com efeito, estabeleceu-se junto com a apropriação divina deste território uma forma de entrada na vida adulta por intermédio do que seria, digamos, um exercício ritual de pecados. Os jovens, condenados no púlpito por farras, drogas e bebedeiras, são absolvidos nas conversas entre familiares, e mesmo incentivados à boca pequena, pelas narrativas em que o próprio pastor é descrito como antigo membro desta "confraria". Em suma, é atribuída a eles, desviados, uma condição de liminaridade peculiar, ainda que tratada de forma ambivalente, cujo sentido seria dado pela passagem da infância para o universo dos homens adultos. Bebem, usam drogas, jogam futebol, dançam e praticam a "fornicação". Pecado e masculinidade andam juntos na vila e assinalam os caminhos preferenciais do diabo. ${ }^{20}$

Distantes da igreja, mas não surdos às suas admoestações, os desviados parecem carregar uma bússola evangélica corporificada que os obriga a se situarem preferencialmente nas margens dos lugares e dos acontecimentos centrais da vila. Inclinam-se com respeito à apropriação divina do território. Assim, desviados, afastados e não-evangélicos — todos os graus de distância da igreja e de proximidade com o mal diabólico reconhecidos na vila — participam de uma resistência, às vezes surda, às vezes estridente, e mesmo culpada, aos limites que lhes são impostos para que a utopia evangélica se realize no lugar.

Foi a partir desses lugares marginais que Carlos e Bruno se envolveram num comportamento julgado por seus pares e pela igreja como feitiçaria.

Era um dia chuvoso na vila... e eles e seu grupo de amigos estavam no "Canto Brabo", bebendo e consumindo outras drogas (como maconha e cocaína, especialmente esta última, que goza da preferência de muitos jovens...) quando resolveram preparar um frango assado. Bruno foi até a sua casa e pegou um galo, voltou e entregou a Carlos, que logo quebrou o pescoço do bicho e começou a depená-lo. Eles levaram o animal para uma casa abandonada ali perto e tentaram acender uma fogueira, mas as madeiras estavam todas molhadas, o que impossibilitou o intento. Aí, Carlos falou: "quer saber, vou comer assim mesmo" - e, agora, é ele que continua contando: "Comecei a dar umas dentadas, mastigava, mastigava, mastigava e engolia, depois joguei nas mãos do Bruno e ele também deu umas dentadas. A gente ficou com a cara toda ensanguentada, igual a um vampiro, quando eu mordia a pele, ela esticava e, quando arrebentava, espirrava sangue pela cara toda. Aí eu joguei o frango nas costas e saímos andando pelo meio da vila com a cara toda ensanguentada, rindo alto e com o galo sem cabeça sangrando pelas costas [...] Eu expulsei gente dos dois bares, cheguei naquele bar do lado da casa do Negão e joguei o bicho todo sangrando em cima do balcão, e pedia para preparar para mim, aí espirrava sangue nos outros, sujei o bar todo de sangue... Até falei que ia virar macumbeiro. ${ }^{21}$ 
Os dois protagonistas desta encenação de um ritual de macumba contam esta história em que seus gestos são descritos, de início, como resultantes das finalidades práticas que queriam atingir, mas que ganham um sentido progressivamente provocador que se revela para todos como diabólico. Se, no começo, visariam improvisar ludicamente os meios de assar um galo numa fogueira, pela falta de instrumentos e de habilidade, acabaram usando os próprios dentes sobre uma carne crua e sangrenta. As mordidas no galo cru aparentemente teriam provocado uma guinada na orientação e na intencionalidade de seus gestos que, sem dúvida, para os bons entendedores, indicavam de modo preciso a ação do diabo. Com a cara toda ensanguentada, igual a vampiro, disse um deles, deliberadamente buscaram amedrontar e assustar as pessoas. Ou, em outros termos, fizeram dos seus gestos que imitavam uma possessão diabólica uma paródia, um ato carnavalesco, através do qual debocham, ridicularizam e se distanciam criticamente da Palavra divina que é capaz de salvá-los. ${ }^{22} \mathrm{E}$, segundo eles, de fato, as pessoas reagiram às suas atitudes, traduzindo-as — para os que porventura ainda não tivessem entendido - no sentido de que os dois tinham virado macumbeiros.

O modo improvisado e desajeitado de matar o galo revela a não-intencionalidade inicial em realizar um ritual, tal qual uma macumba seria nas imagens pentecostais. No entanto, o acaso que possibilitou o redirecionamento dos seus gestos torna ainda mais forte, para os que assistiram a cena e para eles próprios, a orientação diabólica de suas ações. O diabo, assim encarnado, transforma-se num ser que ri, que gargalha das tentativas da igreja de mantê-lo aprisionado nas margens do seu território.

Bruno e Carlos reconhecem que seus gestos se parecem com aqueles que os pastores apontam como próprios de uma entidade diabólica, sem que tenham tido esta experiência subjetiva como membros do candomblé. Não há divergências de interpretação, portanto. Com efeito, a experiência religiosa dos protagonistas destes dois casos é bastante distinta. Os dois jovens desviados foram acusados de estar possuídos por um diabo cuja identificação foi feita pelo pastor Pedro, da comunidade. Este último considerou que a macumba ali realizada teve como seu autor uma Pomba-Gira, quer dizer, uma entidade feminina identificada como o espírito de uma prostituta. Apesar de essas manifestações serem relacionadas com práticas diabólicas, elas diferem, ao menos em grau, de uma "presentificação" do diabo na praça central da vila, durante o dia e defronte à igreja. A maioria desse grupo de idade, assinalemos, não costuma desafiar a igreja de forma ostensiva, como fizeram Carlos e Bruno ao trazerem o diabo "em pessoa" para o espaço público, parodiando/realizando uma cena de feitiçaria.

Constituir-se como adulto implica realizar escolhas morais que permitam abandonar, depois de experimentá-las, as seduções do demônio. Este é ao me- 
nos o projeto que lá se encontra. O destino dos desviados depende, em consequência, do que farão da herança familiar que eles carregam, cuja importância maior ou menor, nas hierarquias locais, ajuda a estabelecer para os jovens certas expectativas quanto ao futuro que terão. Embora Bruno não desacredite a sua salvação futura, não deixa de hesitar sobre as benesses ofertadas pelo caminho de redenção. Este envolve dificuldades bem mais significativas para ele do que aquelas vividas por alguns de seus companheiros de farra, mais claramente vinculados às famílias privilegiadas pela hierarquia da igreja.

Carlos, por sua vez, tampouco carrega um fardo leve como herança familiar. Os pais de ambos, trabalhadores na pesca, reconhecidos por suas dificuldades com a bebida, apesar de herdeiros pelos laços de família da tradição evangélica, jamais usufruíram de uma boa posição, e há muito tempo são considerados pela igreja como afastados. Foi por intermédio de suas mães que os dois preservaram, apesar de tudo, vínculos ainda que rarefeitos com a igreja e, em função de seus pais, parecem partilhar de certo ceticismo quanto às possibilidades de melhorias em suas vidas terrenas. O ceticismo, no entanto, não abala as convicções sobre o antagonismo cósmico entre o Bem e o Mal como guia de suas existências.

Depois da cena protagonizada pela Pomba-Gira, um dos jovens buscou se reaproximar da igreja, abandonou a bebida e se casou. O outro, ao contrário, intensificou a sua identificação com o desvio e suas margens para além do que seria uma liminaridade ritualmente controlada. Apesar da estigmatização que passou a sofrer, continuou a ter um comportamento de desafio e de deboche que marca a sua distância da igreja. Este comportamento, no entanto, não engendrou até agora uma associação sua com a criminalidade, como aconteceria muito rapidamente em outras margens sociais. Mas, em contrapartida, provocou o seu isolamento social crescente. Imperceptivelmente, um movimento de evitação começou a operar, excluindo-o de muitos momentos de sociabilidade.

Como previsto, na condução da vila, o pastor se guia por critérios evangélicos, o que inclui uma orientação permanente para os diferentes serviços ofertados pelo Estado no sentido de vivificar as fronteiras da comunidade com as forças emanadas pelo Espírito Santo. A jurisdição sobre os desviados é a mais sensível, já que esta se contrapõe às orientações criminalizantes do Estado, efetivadas em outros lugares pelas suas forças policiais. O posto policial, situado também na praia, indica que este espaço liminar é aquele de observação permanente por parte da polícia. No entanto, não se veem as forças da ordem dar demasiada atenção aos movimentos que ali ocorrem. Prevalece - o que contrariou a minha expectativa - certo distanciamento e mesmo uma evitação relativa em identificar e perseguir ali, na vila, o 
caminho das drogas e efetivar a criminalização dos drogados. A relativa liberdade que estes usufruem, embora sempre acompanhada pelas ameaças do fogo do inferno, contrasta fortemente com o que acontece nas vizinhanças, onde a polícia intervém com violência. A associação do desvio com a criminalidade nas margens da vila é ciosamente evitada pela igreja para os que pertencem à comunidade, e cujo futuro previsto é a integração à igreja, em um momento talvez não muito distante, em que partilharão plenamente a herança evangélica que abençoou o seu território.

O fato de não reduzir os indivíduos desviados à condição de criminosos se deve, em primeiro lugar, às possibilidades que lhes são oferecidas por intermédio da conversão, que prevê a sua inserção plena na comunidade de crentes. Em segundo lugar, neste caso específico, o pertencimento a um lugar santificado, em que o próprio Estado reconhece como configurado e controlado pelos valores evangélicos, faz do pecado algo mais claramente provisório no desenrolar da existência. No interior de seu espaço santificado, podemos aventar, a comunidade evangélica antecipa, com a volta dos desviados à igreja, a vitória de Deus sobre aqueles que buscam derrotá-la a partir de suas margens e becos. Como explicitou um jovem que buscava o seu retorno à igreja: não quer de forma alguma perder o dia do arrebatamento da sua igreja para o céu, isto é, o dia, talvez próximo, do Juízo Final.

A vigilância, vagamente distraída da polícia sobre os jovens, parece se apoiar no respeito às autoridades locais, mas também no compartilhamento da visão evangélica que assegura para os "de fora" o quanto é positiva e eficaz a agência divina definindo o seu território e a unidade moral da comunidade. Sob o controle comunitário, os jovens raramente são interpelados pelo Estado, através das suas regras abstratamente consideradas. A relação com este passa pela mediação do pastor e pelos valores defendidos por sua igreja.

Disse que segmentos do Estado participam da ordem pública na comunidade evangélica através de um comportamento que exprime uma afinidade com os critérios de gestão da vila, implementados pela igreja. Se assim não fosse, a maioria dos servidores do Estado não teria sido indicada pela igreja. Embora não isolada, a comunidade evangélica é protegida, em parte, da fragmentação social, da presença de outras instituições e igrejas pela redoma que a envolve, construindo-a como um "enclave" pentecostal. Este assume a forma de interdições, mais ou menos ocultas, relativas à presença no local de outros grupos religiosos e laicos.

O filtro da igreja participa das linhas de força que atravessam as dinâmicas políticas no município. Os professores são orientados a evitar temas controversos, o calendário da escola é estruturado em conformidade com a igreja. A polícia, quando é ativada, sabe perfeitamente bem como escolher 
seus suspeitos. Os encarregados dos serviços de limpeza reconhecem a importância política de limpar melhor a praça onde se encontra a igreja e a casa do pastor, e sabem em que lugares o lixo pode se acumular sem problemas. A eletrificação do lugar também acompanhou os limites do território. Assim, o Estado se apresenta na vila em conformidade com os valores e as demandas da elite religiosa local, controlando o fluxo dos serviços e as relações de troca com as instituições supralocais. Não seria absurdo dizer que os agentes governamentais se "pentecostalizaram" ali dentro e, deste modo, ao corroborarem as indicações da igreja, reconhecem como una e indivisível a totalidade religiosa e cultural que se sobrepõe a este território.

\section{Notas finais}

Não têm sido inteiramente inócuos os esforços evangélicos para "pentecostalizar" os segmentos do Estado com os quais se relacionam. O drama enfrentado por Alice também pode ser visto a partir deste prisma. A conversão a uma igreja pentecostal apresentou-se rapidamente para ela como meio de transcender suas faltas morais e o seu embricamento com os conflitos locais diante das interpelações identitárias promovidas pelo Estado. A sua resposta não foi a conversão. Somente esta teria permitido um exercício de purificação permanente e uma ruptura efetiva com os diabos locais. No entanto, muitos como ela cultivam uma distância relativa das trincheiras da Batalha Espiritual, orientando-se por esse caminho dúbio de adesão parcial à palavra evangélica. Alice reconheceu a precariedade dos seus recursos mágicos naquelas circunstâncias, sem adotar, como resultado desta percepção, a Batalha Espiritual como guia para a sua existência. A convivência conformada com o mal diabólico apresenta-se assim como uma forma possível de resistência marginal à suspeição do Estado e aos imperativos comunitários propostos pelos evangélicos.

O ator pentecostal na favela apresenta-se como portador de uma alteridade positiva em relação ao mundo e também à favela como espelho das relações terrenas, por natureza maléficas. A filiação religiosa evangélica altera, em consequência, as formas pelas quais o indivíduo pentecostal participa dos circuitos de trocas que envolvem os que habitam as margens. Distantes da macumba, oferecem a conversão para aqueles que se encontram nas margens e que, segundo podemos ler no relato abaixo, garantiriam o afastamento até mesmo dos traficantes das entidades afro-brasileiras. Abririam a possibilidade, inclusive, de alterar, no futuro, os vínculos com o mal diabólico tão presentes na comunidade por intermédio do tráfico: 
A forte presença evangélica no Chatô não é visível apenas nos pequenos templos que se multiplicam pelas ruelas, ou nos homens e mulheres com suas bíblias debaixo do braço, estando também, inesperadamente, em monumento erguido pelos traficantes em uma área de grande visibilidade do morro. A bíblia esculpida em pedra e guardada numa redoma representaria uma homenagem do "movimento" à fé de seus parentes e amigos. "No fundo, no fundo, a vontade deles também é de encontrar Jesus", explicou-nos um dos missionários da Jovens com uma Missão (Jocum). Não são poucos os que atribuem a diminuição da violência no Chatô a uma "quase-conversão" por parte dos traficantes, explicação que, além disso, revela o forte preconceito enfrentado pelas religiões afro-brasileiras: "pelo menos eles não praticam mais a macumba, não precisam matar para agradar os santos", comentou um dos entrevistados (Chinelli et alli $2005: 137) .^{23}$

A morte social, física e simbólica da pessoa subsumida ao diabo que o tráfico sintetiza se contrapõe à libertação propiciada pela igreja, cujos efeitos podem se efetivar, ainda que provisoriamente, antes mesmo da conversão. Para um pastor da favela mencionada, segundo este artigo, estes seriam sinais claros de que se devia à igreja uma diminuição da barbárie. E, desta forma, vemos a valorização das igrejas evangélicas como mediadoras entre as periferias e os que estão do "outro lado" da cidade. Não é à toa que os religiosos evangélicos se proclamam os principais artífices para uma futura reconfiguração moral desses espaços marginais. ${ }^{24}$

A acusação de feitiçaria nos dois casos encontra-se associada ao universo pentecostal em sua relação com territórios/comunidades. Tratei mais precisamente de como certas enunciações envolvendo feitiçaria "afetaram" os protagonistas dessas histórias. ${ }^{25}$ Busquei ampliar a sua compreensão mostrando que a força dos enunciados de feitiçaria neste quadro encontra-se ligada também a processos de diabolização, relacionados à criminalização de certas figuras sociais e de territórios situados nas margens. ${ }^{26}$ Sugeri que as identificações promovidas pelo Estado favorecem o universalismo pentecostal e seus chamados à transcendência e à ruptura com os enraizamentos religiosos locais. Como resultado, indico a mutação religiosa e política que se passa no interior desses territórios nos quais cresce a palavra evangélica e o seu horizonte político, que os orientaria a se tornarem os futuros responsáveis pela reconfiguração moral de tais territórios.

Valorizo também, como resultante dessas situações, a participação, a resistência e o desconforto dos meus protagonistas como objetos e sujeitos de ações de magia e de feitiçaria. Embora estejam convencidos pela palavra 
acusadora e redentora do pentecostalismo e concernidos a ela, descrevo, por meio de suas atitudes, uma acolhida mitigada desses imperativos políticoreligiosos, um relativo distanciamento de seus princípios, o que engendra uma adesão precária, resistente e frequentemente provisória à ordem social e moral que lhes é ofertada.

Recebido em 08 de dezembro de 2008

Aprovado em 22 de setembro de 2009

Patricia Birman é professora da UERJ e pesquisadora do CNPq. E-mail: < patriciabirman@terra.com.br>

\section{Notas}

${ }^{1}$ Realizei entre 1993 e 1997 vários períodos de trabalho de campo em uma pequena favela, um pequeno enclave situado na zona abastada da cidade do Rio de Janeiro, onde busquei acompanhar um grupo de recém-convertidos ao pentecostalismo. Para este trabalho foi fundamental a colaboração de Patricia Guimarães. Foi no ano de 2004 que iniciei minha pesquisa na "comunidade de crentes" de que trato neste artigo, a qual perdurou até 2008 e contou com uma intensa participação de estudantes, aos quais agradeço, resultando em quatro monografias e em uma dissertação de mestrado (Cf. Bakker 2008; Cretton 2007; Lopes 2009 e Mendonça 2009). Agradeço também a Roger Sansi os comentários que fez à primeira versão deste texto que lhe foi enviado como esboço para um colóquio, "Feitiçaria no Atlântico Negro", em 2006, do qual infelizmente acabei não participando. Agradeço também a leitura cuidadosa de Márcia Leite e de Marc Piault. Apresentei este texto no Seminário do CEAf (Centre d'Études Africaines), coordenado por Michel Agier, e na UFJF, a convite de Marcelo Camurça. Os comentários críticos que recebi de todos nessas ocasiões foram extremamente úteis para a finalização deste artigo.

${ }^{2}$ Bayart, Geschiere \& Nyamnjoh (2001:180). Cf. também Noiriel (2005 e 2007) e a noção foucaultiana de biopolítica sobre os processos de identificação e identidade e sua relação com o Estado.

${ }^{3}$ Refiro-me a "margens" enquanto "periferia", frequentemente associada a lugares onde restam os que falta "civilizar". Veena Das e Deborah Poole (2004), que elaboraram esta noção, valorizam também a ideia de que o Estado, longe de estar ausente das margens, é um ator fundamental na configuração destas, além de também 
ser conformado pelas dinâmicas locais. Argumentam assim de forma bastante incisiva contra a ideia de que existe uma "falta" de Estado nas "margens". Esta ideia de falta tem permitido, com efeito, ignorar o quanto o Estado participa das configurações políticas e sociais das periferias.

${ }^{4}$ Para uma discussão rica sobre o conceito de cultura e de suas tendências essencialistas no Brasil, bem como sobre seus desenvolvimentos socialmente discriminatórios, ver Andreas Hofbauer (2006) e Jean-François Véran (2003). Para um comentário crítico a respeito do emprego da noção de comunidade em relação às favelas, ver nota 5, onde explicito o argumento de Lícia Valladares. Ver também Duarte (1991), Leite (2000 e 2008) para as relações entre cidadania e comunidade, e Birman (2008) para uma discussão dos usos da categoria de comunidade relacionados a favelas.

${ }^{5}$ Lícia Valladares chamou a atenção, com razão, para a forma essencialista de construção das favelas por parte dos cientistas sociais. Nestas unidades territoriais, mas também culturais e de classe, os pesquisadores poderiam assim facilmente "buscar" a forma dos pobres de se comportarem em relação à sexualidade, à religião, à política etc. Análises variadas descrevem os moradores de favela através de atributos sociais, culturais e morais que seriam homogêneos e provenientes da condição comum de moradores. Como aponta criticamente esta autora: "Na favela, os pobres estão na sua casa. Na medida em que formam uma cidade dentro da cidade, a cidade ilegal dentro da cidade legal, os residentes demarcam seu território, verdadeiro enclave onde a marca identitária é onipresente. Assim percebida, a favela teria uma economia própria, leis intramuros e códigos particulares, desenvolvidos nesses espaços entregues à própria sorte e abandonados pelos poderes públicos" (Valladares 2005:151). Se é necessário descartarmos esta percepção criticada por Valladares pelo seu essencialismo e pela totalização abusiva que assim se construiu, não podemos, no entanto, desconsiderar o quanto estas imagens totalizantes são necessariamente levadas em conta pelos habitantes destes lugares nas estratégias que constroem para suas vidas e nas relações de poder que obrigatoriamente lhes concernem.

${ }^{6}$ O trabalho de campo realizado nesta comunidade evangélica contou com a participação de vários estudantes, aos quais agradeço enormemente a colaboração: André Bakker, Eduardo Pereira, Vicente Cretton, num primeiro momento, e mais recentemente, Angélica Ferrarez, Helena Guilayn, Natânia Lopes e Mariana Mendonça.

${ }^{7}$ Suponho que a maioria das famílias tenha ao menos um dos seus membros na igreja. E creio que é este o critério demográfico local, cujas premissas religiosas discutirei mais adiante, o que permite à igreja dizer que nesta vila "a maioria" é evangélica.

${ }^{8}$ Cf. Patricia Birman (2006a, 2008) para a concepção local da comunidade de crentes e sua relação com o território. Para uma discussão do espaço no interior da vila, ver Vicente Cretton (2007), e para a percepção dos religiosos a respeito da presença de Deus e do Diabo, ver André Bakker (2008).

${ }^{9}$ Cf. Cecília Mariz (1999) para uma discussão e revisão bibliográfica sobre a Batalha Espiritual. André Bakker (2008) fez uma excelente descrição etnográfica da 
leitura que os evangélicos fazem da mídia laica. Através da percepção evangélica, os jornais televisivos, com o seu rosário de crimes e violências, comprovam cotidianamente a validade dos versículos bíblicos e, sobretudo, as previsões do Apocalipse.

${ }^{10}$ Estou utilizando "crentes" e "evangélicos" praticamente como sinônimos. O termo evangélico, porém, é aquele que os religiosos utilizam preferencialmente quando se referem à totalidade dos protestantes, incluindo os grupos pentecostais. Ultimamente este termo tem sido mais usado porque possui uma conotação social mais positiva do que pentecostal ou crente. Este último é mantido por mim na medida em que é também utilizado no interior da "comunidade de crentes" que eu estou analisando.

${ }^{11}$ Feitiçaria é o termo privilegiado por Edir Macedo, líder da IURD, para descrever os procedimentos que atribui aos cultos afro-brasileiros. Mais de dez anos se passaram desde a primeira edição de Orixás, caboclos e guias, deuses ou demônios? - o livro mais conhecido deste autor, que associa abertamente os cultos afro-brasileiros com crimes e monstruosidades: "um ex-pai de santo contou como, em uma ocasião, fez um trabalho para que um rapaz ficasse louco. Ele entrou num cemitério à meia-noite, e, depois de abrir uma sepultura onde havia um defunto enterrado há apenas cinco horas, retirou o cadáver (era um rapaz de vinte e poucos anos) decepando-lhe a cabeça e, no lugar dela, colocando uma outra, de cera, trabalhada com o nome de seu inimigo... Pode, por acaso uma seita que determina tais práticas ser considerada religião? Vemos coisas assim serem publicadas quase que diariamente em nossos jornais e, já que a nossa sociedade não pode tomar medidas contra isso, somos obrigados, em nome de Jesus, a levantar a nossa voz! Uma ex-mãe de santo confidenciou-me também que trabalhou num terreiro em Recife, onde compravam crianças recém-nascidas para com elas fazerem sacrifícios nos cemitérios ou encruzilhadas. Tivemos em 1979 um caso em que a polícia descobriu uma fazenda onde os orixás, caboclos e guias pediam semelhante coisa" (bispo Macedo 2000:108).

No momento de sua publicação, a Batalha Espiritual movida pela IURD contra as manifestações diabólicas dos afro-brasileiros e a idolatria católica já tinham sido objetos de muitos debates e controvérsias. Nada disso, contudo, impediu o crescimento desta igreja e a expansão de sua doutrina.

\author{
12 "Em cada canto da cidade tem uma favela \\ em cada canto da favela tem um traficante \\ E algum traficante sempre tem uma mãe que é crente \\ Que ora pelo filho desesperadamente \\ Cansada de chorar, de lutar, de sofrer \\ Ela acredita que um dia ele vai se arrepender \\ E lembrar de tudo aquilo que ela ensinou \\ Voltar às origens ou ao que sobrou \\ De uma vida pobre eu sei \\ Não se espera muito \\ Mas o amor e o carinho da mãe estão sempre junto \\ Que vida é essa?
}


Sempre se perguntava

Que Deus é esse?

Que parece não fazer nada

É verdade, pouca coisa mudou de lá pra cá

Mas o amor e a fé em Deus nunca hão de faltar

Vida difícil sim

Injusta jamais

Caminhando pela vida em busca da paz"

(DJ Alpiste apud Oosterbaan 2006:6). Regina Novaes (2003) descreve o perfil de Alpiste no campo do hip hop.

${ }^{13}$ Os nomes de todas as pessoas mencionadas são fictícios. Enquanto candomblé é um termo valorado positivamente pelos membros deste culto, o termo macumba guarda um caráter pejorativo, frequentemente associando suas práticas a rituais maléficos.

${ }^{14}$ Nesta época, os traficantes controlavam relativamente as fronteiras da pequena favela, mas não intervinham abertamente no direito de ir e vir dos habitantes e de estranhos. Este controle foi aumentando progressivamente em todas as chamadas comunidades com o crescimento do tráfico e da guerra que se instaurou na cidade do Rio de Janeiro.

${ }^{15}$ É preciso considerar que o pentecostalismo, ao transformar as entidades e os espíritos em diabos, exige dos conversos um rompimento com estas no sentido de desenraizá-los de si, ao invés de mantê-los como parte das suas identidades construídas localmente. A transcendência do mal pentecostal (cf. Robbins 2008) permite que a convivência com este seja pensada através de outra relação com o tempo: não mais o tempo em que as práticas religiosas se enraízam na pessoa e nos lugares, por meio do cultivo de uma "tradição", garantida pela circularidade das trocas religiosas, mas um tempo cujo desenvolvimento dependerá do rompimento com o passado pecador. Veremos, pois, como o mal para os evangélicos, para ser controlado, exige uma ruptura com a vida "no mundo" e terá para os indivíduos que almejam a salvação um sentido sempre provisório que aponta para a sua eliminação progressiva. Esta outra relação com o tempo não pode ser separada do que Appadurai apresentou como um movimento de construção de identidades que não toma o pertencimento a um lugar como condição para a sua realização (cf. Birman 2006 e 2009).

${ }^{16}$ Pude contar para a redação deste texto tanto com minha experiência direta com Alice, quanto com uma entrevista realizada por Patricia Guimarães.

17 "Zé Pilintra" é o nome de uma entidade que corresponde à figura tipificada de um malandro, figura que nos anos 50 foi construída como exemplar dos tipos populares, moradores das favelas cariocas: amigo do samba, inimigo do trabalho e capaz de sobreviver através de pequenos golpes de esperteza.

${ }^{18}$ Para uma análise a respeito da importância do circuito de trocas entre os religiosos e suas clientelas na constituição das casas de culto e de suas lideranças, ver o trabalho já clássico de Peter Fry (1982). Cf. também José Renato Baptista (2007). Joel 
Robbins (2008) chama a atenção para o que seria um traço comum ao pentecostalismo que contrasta com cultos "tradicionais": como uma religião que separa e distancia o transcendental e o mundano de uma maneira radical, o pentecostalismo possibilitaria aos indivíduos o reconhecimento de uma falta de controle e de poder sobre as suas condições de existência. Esta interpretação me parece se adequar perfeitamente à experiência que trago por meio do relato de Alice. Observo que, neste sentido, a dimensão transcendente que é posta em relevo é a do Mal. Alice não experimentou a grandeza divina, mas sim a força impessoal e maléfica do Diabo.

${ }^{19}$ Kelly Hayes (2004) fornece uma excelente análise etnográfica dos recursos sociais e familiares que uma mãe-de-santo no Rio de Janeiro possui por intermédio das suas entidades. Destaca a importância da agência atribuída às entidades e suas formas de participar dos circuitos de trocas da sua "dona". Ver também neste sentido a análise precursora de Véronique Boyer (1993) sobre os elos das mulheres com as suas entidades invisíveis.

${ }^{20}$ A categoria de "desviados" não se aplica a mulheres. E, de fato, as mulheres da vila evitam participar desses eventos pecaminosos. Estes ocorrem no mais das vezes com a participação de mulheres "de fora", como turistas eventuais ou, mais frequentemente, entre homens.

${ }^{21}$ Este relato provém de uma conversa registrada por Eduardo Pereira, em 2006, que na época fazia parte da minha pesquisa como bolsista de iniciação científica.

${ }^{22}$ Refiro-me aqui, evidentemente, à carnavalização como ação disruptiva e inventiva tal como descrita por Bakhtin (1987).

${ }^{23}$ De modo geral, a literatura sugere que a ação missionária pentecostal é direcionada à conversão de indivíduos e não de territórios. No entanto, vemos aqui, em relação à favela e também no caso da comunidade de crentes, que o discurso da conversão possui fortes componentes territoriais: "expulsar os demônios" ganha um sentido de conquista e de purificação em relação a um mundo marcado pela barbárie. O trabalho de Philippe Gonzales (2008:50) me pareceu precioso em relação a este caráter possível da ação evangélica. Como diz ele: "A evangelização é uma incursão em território inimigo e uma subversão da ordem que nele reina. Os evangélicos têm consciência de trabalhar no cruzamento entre dois mundos, sua ação tendo por objetivo libertar os cativos do demônio e introduzi-los na realidade divina... A ação missionária aparece então como uma fenda em terreno inimigo e visa instaurar uma nova clivagem espiritual do território".

${ }^{24}$ Cristina Vital da Cunha (2009) chama a atenção para o fato de que na "guerra" que a polícia vem desenvolvendo contra os "traficantes" e os "bandidos", as entradas nos territórios de favela foram frequentemente acompanhadas pela destruição dos objetos dos cultos afro-brasileiros ("despachos") nas suas vias públicas. Lembremos aqui o trabalho de Yvonne Maggie neste livro e também aquele sobre o "Museu da Polícia" (1992) em que a crença na feitiçaria ganhava sua positividade através da participação da polícia. 
${ }^{25}$ Estou me referindo ao verbo "afetar" no sentido utilizado por Favret-Saada (1977 e 2009), quer dizer, sem opor e separar a experiência emocional dos atores das suas relações sociais e simbólicas, bem ao contrário, considerar as afetações como essenciais para compreender os sentidos da feitiçaria. Favret-Saada (2009:146) reclama um ponto de vista que a distancia dos trabalhos antropológicos que se manteriam presos "às produções culturais do entendimento".

${ }^{26}$ É interessante neste sentido a perspectiva aberta por alguns trabalhos quanto à retirada da feitiçaria do espaço que lhe tem sido reservado pela "Grande Partilha": esta é sempre alocada nos grupos populares e, de preferência, do "sul", e ausente entre as elites pensantes e as sociedades do "norte" (Cf. Favret-Saada 2009; Pels 2003; Geschiere 2003).

\section{Referências bibliográficas}

BAPTISTA, José Renato. 2007. “Os deuses vendem quando dão: os sentidos do dinheiro nas relações de troca no candomblé". Mana. Estudos de Antropologia Social, 13(1):7-40.

BAKKER, André. 2008. Deus, o diabo e a televisão: mídia moderna de massa e Pentecostalismo em uma comunidade evangélica. Dissertação de mestrado, PPCIS/UERJ.

BAKHTIN, Mikhail. 1987. A cultura popular na Idade Média e no Renascimento. O contexto de François Rabelais. São Paulo/Brasília: Editora Hucitec, Editora da UNB.

BAYART, Jean-François; GESCHIERE, Peter \& NYAMNJOH, Francis. 2001. "Autochtonie, démocracie et citoyenneté en Afrique". Critique Internationale, 10:126-195.

BIRMAN, Patrícia. 1996. "Cultos de possessão e pentecostalismo no Brasil: passagens". Religião e Sociedade, 17(1-2):90-109.

. 2003. "Imagens religiosas e projetos para o futuro". In: P. Birman (org.), Religião e espaço público. Brasília: Attar Editorial/ CNPq-Pronex. pp. 235-254.
— 2006a. "O Espírito Santo, a mídia e o território dos crentes". Ciências Sociais e Religião, 8:41-62. . 2006b. "Future in the miror: media, evangelicals, and politic in Rio de Janeiro". In: Birgit Meyer \& Annelies Moors (eds.), Religion, media, and the public sphere. Bloomington: Indiana University Press. pp. 52-72. . 2008. "Favela é comunidade?". In: Luiz Antônio Machado da Silva (org.), Vidas sob o cerco: violência e rotina nas favelas do Rio de Janeiro. Rio de Janeiro: FAPERJ. pp. 99-114.

. 2009. Evangelical forms of living the favela. Paper apresentado no Seminário Global Prayers, Metrozone, Berlin.

. \& LEITE, Márcia Pereira. 2000. "Whatever happened to what used to be the largest catholic country in the world?". Daedalus-Journal of the American Academy of Arts and Sciences, 29(2):271-290.

BOYER, Véronique. 1993. Femmes et cultes de possession au Brésil. Les compagnons invisibles. Paris: L'Harmattan. 
CHINELLI, Filipina; FREIRE-MEDEIROS, Bianca; MEDEIROS, Lidia. 2005. "Reflexões sobre a percepção de direitos e formas alternativas de acesso à justiça com base em um estudo de caso em uma favela do Rio de Janeiro". Interseções, 7:131-146.

CRETTON, Vicente. 2007. Território sagrado: A geografia das relações sociais em uma comunidade evangélica. Monografia em Ciências Sociais, UERJ, mimeo.

DAS, Veena \& POOLE, Deborah. 2004. "State and its margins: comparative ethnographies". In: DAS, Veena \& POOLE, Deborah (orgs.), Anthropology in the margins of the State. New Delhi: Oxford University Press. pp. 3-34.

DUARTE, Luiz Fernando. 1991. "Legalité et citoyenneté dans le Brésil contemporain: la question du particularisme des quartiers populaires à partir de l'observation anthropologique d'une experience d'aide légale et d'education civique". Cahiers du Brésil Contemporain, 17:17-29.

FARIAS, Juliana. 2008. "Da asfixia : reflexões sobre a atuação do tráfico de drogas nas favelas cariocas". In: Luiz Antônio Machado da Silva (org.), Vidas sob o cerco: violência e rotina nas favelas do Rio de Janeiro. Rio de Janeiro: FAPERJ. pp. 173-190.

FAVRET-SAADA, Jeanne. 1977. Les mots, la mort, les sorts. La sorcellerie dans le Bocage. Paris : Gallimard. - 2009. Désorceler. Paris: Éditions de l'Olivier.

FRIGERIO, Alexandro \& ORO, Ari Pedro. 2003. "Guerre sainte dans le Cône sud latino-américain: pentecôtistes versus umbandistes". Journal de la Societé des Américanistes, 91(2):185-218.

FRY, Peter. 1982. Para inglês ver. Identidade e política na cultura brasileira. Rio de Janeiro: Zahar Editores.
GESCHIERE, Peter. 2003. "On witch doctors and spin doctors: the role of 'experts' in african and american politics politics". In: Birgit Meyer \& Peter Pels (orgs.), Magic and modernity. Interfaces of revelation and concealment. Stanford: California University Press. pp. 159182.

GONÇALVES DA SILVA, Vagner (org.). 2007. "Entre a gira de fé e Jesus de Nazaré". In: Intolerância religiosa. Impactos do neopentecostalismo no campo religioso afro-brasileiro. São Paulo: EdUSP. pp. 191-260.

GONZALES, Philippe. 2008. "Lutter contre l'emprise démoniaque. Les politiques du combat spirituel evangélique". Terrain, 50:44-61.

GIUMBELLI, Emerson. 2002. O fim da religião: dilemas da liberdade religiosa no Brasil e na França. São Paulo: ATTAR Editorial.

. 2003. O "chute na santa": blasfêmia e pluralismo religioso no Brasil". In: Patricia Birman (org), Religião e espaço público. São Paulo: ATTAR Editorial. pp.169-198.

HAYES, Kelly. 2004. Magic at the margins: macumba in Rio de Janeiro. An ethnografic analysis of a religious life. PhD in History of Religion, University of Chicago.

HOFBAUER, Andreas. 2006. Uma história do branqueamento ou o negro em questão. São Paulo: FAPESP/ UNESP.

LEITE, Márcia Pereira. 2000. “Entre individualismo e solidariedade: dilemas da política e da cidadania no Rio de Janeiro". Revista Brasileira de Ciências Sociais, 44:73-91. - 2008. Para além da metáfora da guerra: violência, cidadania, religião e ação coletiva no Rio de Janeiro. São Paulo: Attar Editorial/ PronexMCT/CNPq. No prelo.

LOPES, Natânia. 2009. Uma comunidade que não é deste mundo. Trabalho 
de monografia de final de curso, PPCIS/ UERJ. Mimeo.

MACHADO DA SILVA, Luiz Antonio (org.). 2007. "Rompendo o cerceamento da palavra: a voz dos favelados em busca de reconhecimento". Relatório de pesquisa, FAPERJ. Mimeo.

- \& LEITE, Márcia Pereira. 2007. "Violência, crime e polícia: o que os favelados dizem quando falam desses temas?". Revista Sociedade \& Estado, 22(3):545-592.

MAFRA, Clara. 1998. "Drogas e símbolos: redes de solidariedade em contextos de violência". In: A. Zaluar \& M. Alvito (orgs.), Um século de favela. Rio de Janeiro: Editora FGV. pp. 277-298.

MAGGIE, Yvonne. 1992. Medo de feitiço. Rio de Janeiro: Arquivo Nacional.

MARIANO, Ricardo. 1996. "Os neopentecostais e a teologia da prosperidade". Novos Estudos, 44:24-44.

MARIZ, Cecília. 1999. "A teologia da batalha espiritual: uma revisão da bibliografia". Revista Brasileira de Informação Bibliográfica em Ciências Sociais, 47:33-48.

MACEDO, Edir. 1995. Orixás, caboclos \& guias. Deuses ou demônios? Rio de Janeiro: Editora Gráfica Universal.

MENDONÇA, Mariana. 2009. O paraíso abençoado. Turismo e Religião em uma comunidade evangélica. Trabalho de monografia de final de curso, CIS/UERJ. Mimeo.

OOSTERBAAN, Martijn. 2006. Divine mediations; pentecostalism, politics and mass media in a favela in Rio de Janeiro. Doctoral thesis, University of Amsterdam.

NOVAES, Regina. 2003. “Errantes do novo milênio : salmos e versículos bíblicos no espaço público." In: Patricia Birman (org.), Religião no espaço público. São Paulo: Attar Editorial. pp. 25-33.

NOIRIEL, Gérard 2005. État, nation, immigration. Vers une histoire du pouvoir. Paris: Gallimard.
. (org.). 2007. L'identification. Génèse d'un travail d'État. Paris: Belin.

PELS, Peter. 2003. "Introduction: magic and modernity". In: Birgit Meyer \& Peter Pels (orgs.), Magic and modernity. Interfaces of revelation and concealment. Stanford: California University Press. pp. 1-38.

VALLADARES, Lícia. 2005. A invenção da favela: do mito de origem à favela. com. Rio de Janeiro: FGV Editora.

VERAN, Jean-François. 2003. L'esclavage en héritage Brésil. Paris: Karthala.

VITAL DA CUNHA, Cristina. 2009. Evangélicos em ação nas favelas cariocas: um estudo socioantropológico sobre redes de proteção, tráfico de drogas e religião no Complexo de Acari. Traficantes evangélicos e a globalização: novas formas de experimentação do sagrado em favelas do Rio de Janeiro. Tese de doutorado, Rio de Janeiro,PPCIS/ UERJ.

ROBBINS, Joel. 2008. "Sobre a alteridade e o sagrado em uma época de globalização. O 'trans' em 'transnacional' é o mesmo 'trans' de 'transcendente'"? Mana. Estudos de Antropologia Social, 14(1): 119-139.

SOARES, Luiz Eduardo. 1993. "Dimensões democráticas do conflito religioso no Brasil: a guerra dos pentecostais contra o afro-brasileiro". In: Os dois corpos do presidente e outros ensaios. Rio de Janeiro: Relume Dumará. pp. 203-214. 


\section{Resumo}

Os evangélicos, cotidianamente, através de menções à feitiçaria, cuja origem estaria nos cultos afro-brasileiros, denunciam crimes nefandos e atos de barbárie provocando horror e estarrecimento nos seus ouvintes em igrejas, rádios e televisão. Descrevo dois casos de feitiçaria, objeto de atenção pentecostal, que articulam marginalidade, crime e presença do mal diabólico em duas comunidades. A feitiçaria é a chave com a qual examino alguns problemas relativos à vida em "comunidades": a "diabolização" de territórios periféricos provocada pelas identificações criminalizadoras das suas populações pelo Estado, por um lado, e o combate evangélico ao mal diabólico, por outro. Busco demonstrar que, tanto na comunidade de crentes quanto na favela, os evangélicos respondem por meio do seu combate ao diabo às interpelações do Estado associadas às suas modalidades de identificação de espaços periféricos. Analiso, assim, o sentido assumido pela feitiçaria em relação ao projeto de salvação evangélico e o horizonte social que este busca construir.

Palavras-chave Feitiçaria, Pentecostalismo, Territórios, Favelas, Comunidades

\section{Abstract}

Through their everyday references to witchcraft, allegedly emanating from Afro-Brazilian cults, Evangelical pastors denounce heinous crimes and acts of barbarity that provoke horror and terror in their listeners in church and on radio and television. I describe two allegations of witchcraft by Pentecostal groups, which connect marginality, crime and the presence of diabolical evil in two communities. Witchcraft provides an entry point to examine some of the problems faced by those living in 'communities:' the 'demonization' of peripheral territories provoked by the state's identification of their populations with criminality, on one hand, and the Evangelical battle against diabolical evil, on the other. I look to show that in the community of believers and the favela alike the Evangelicals' battle with the devil is a response to the State's interpellations associated with its modalities of identifying peripheral spaces. In the process, I analyze the meaning assumed by witchcraft within the wider Evangelical project of salvation and the social future it aims to build.

Key words Witchcraft, Pentecostalism, Territories, Favelas, Communities 